\title{
Joint adoption of rice technologies among Bolivian farmers
}

\author{
Jose Maria Martinez ${ }^{1}$ (D), Ricardo A. Labarta ${ }^{2}$, Carolina Gonzalez ${ }^{2}$ and Diana C. Lopera ${ }^{2,3}$ \\ ${ }^{1}$ Department of Agricultural, Food, and Resource Economics, Michigan State University, East Lansing, MI, \\ USA, ${ }^{2}$ Alliance of Bioversity International and CIAT, Cali, Valle del Cauca, Colombia and ${ }^{3}$ HarvestPlus, \\ Cali, Valle del Cauca, Colombia \\ Corresponding author: J. M. Martinez. Email: mart2388@msu.edu
}

(Received 31 July 2020; revised 19 April 2021; accepted 19 April 2021)

\begin{abstract}
Bolivia has disseminated several improved technologies in the rice sector, but the average rice productivity in the country is far below the average trend in Latin America in recent years. Although the economic literature has highlighted the role of agricultural technology adoption in increasing agricultural productivity, gaps remain in understanding how rice growers are deciding to adopt and benefit from available improved rice technologies. Most previous adoption studies have evaluated the uptake of individual technologies without paying attention to the complementarities that alternative improved rice technologies may offer to farmers who face multiple marketing and production needs. This study uses data from a nationally representative sample of Bolivian rice growers to analyze farmers' joint decisions in adopting complementary agricultural technologies controlling for potential correlations across these decisions, as well as the extent of adoption of these practices. Evidence suggests that the decisions on multiple technology adoption are closely related, with common factors affecting both adoption and the extent of adoption. Furthermore, there is a need to better target resource-poor farmers, improve information-diffusion channels on agricultural practices, and better use existing farmers' organizations to enhance rice technology adoption.
\end{abstract}

Keywords: Bolivia; multivariate Probit; rice; technology adoption

JEL: O13; Q12; Q16

\section{Introduction}

Rice productivity in Latin America has shown a considerable increase over recent decades. However, these productivity gains have not been homogeneous across the riceproducing countries in the region. As of 2018, countries such as Argentina, Paraguay, Peru, and Uruguay, and Brazil's southern region, had achieved rice yields between 6.3 and $8.5 \mathrm{t} / \mathrm{ha}$, whereas countries such as Bolivia and Panama remained at production rates below $4 \mathrm{t} / \mathrm{ha}$. In Bolivia, rice production is an essential source of farmers' income

(c) The Author(s), 2021. Published by Cambridge University Press on behalf of the Northeastern Agricultural and Resource Economics Association. This is an Open Access article, distributed under the terms of the Creative Commons Attribution licence (http://creativecommons.org/licenses/by/4.0/), which permits unrestricted re-use, distribution, and reproduction in any medium, provided the original work is properly cited. 
and a critical factor in achieving food security (Calpe 2006). Yet, this country has had the lowest historical yield and second-lowest productivity growth in the region (FAOSTAT 2020).

The economic literature has highlighted the role of agricultural technology adoption in increasing farm productivity and has identified various factors that explain the adoption of different technologies (Feder, Just, and Zilberman 1985; Foster and Rosenzweig 2010). Most studies so far have concentrated on explaining successful technology adoption processes but less on explaining why technology adoption has not successfully reached a larger target population and, therefore, has not translated into considerable yield increases. While many technologies have been promoted in the rice sector of Bolivia and other countries with low rice productivity, few studies have analyzed the factors that may explain the unsuccessful adoption of agricultural technologies.

Studies on the adoption of agricultural technologies have somewhat focused on improved crop varieties. Furthermore, despite the recognized complementarity of improved varieties and other enhanced agronomic practices, most studies have mainly examined separately the decision to adopt agronomic practices from the selection of improved varieties. However, a growing body of the agricultural economics literature has recognized the importance of modeling jointly different decisions in the agricultural technology adoption process to account for potential correlation in alternative adoption decisions (Wu and Babcock 1998). Teklewold, Kassie, and Shiferaw (2013) modeled the adoption of sustainable agricultural practices among Ethiopian maize farmers as a joint process while also incorporating the extent of such adoption into the analysis-measured as the number of practices implemented by farm households (following Wollni, Lee, and Thies (2010)). The authors show that the complementariness and substitutability of agricultural practices are worth analyzing to better understand the drivers of adoption and overall uptake. Building on Teklewold, Kassie, and Shiferaw (2013), other studies have further provided evidence on the suitability of model joint decisions about adopting agronomic practices and improved crop varieties in China (Zeng et al. 2020), Ethiopia (Yirga, Atnafe, and AwHassan 2015; Gebremariam and Tesfaye 2018), Ghana (Donkoh, Azumah, and Awuni 2019), India (Aryal et al. 2018), Kenya (Wainaina, Tongruksawattanab, and Qaima 2016; Kanyenji et al. 2020), Malawi (Ward et al. 2018), Nigeria (Oladimeji et al. 2020), Tanzania (Kassie et al. 2013), and the Chinyanja Triangle (Mponella, Kassie, and Tamene 2018).

This article studies how rice growers in Bolivia make decisions about adopting different agricultural technologies, namely, modern improved varieties (MIVs), mechanization, inorganic fertilization, pesticides, and herbicides. We allow these decisions to be pair-wise correlated and test for the existence of any underlying complementarity. Moreover, the extent of adoption is also modeled as an ordered response, further analyzing how technology adoption factors affect their overall uptake. Using a nationally representative sample of rice growers collected during 2014, the article (a) tests the suitability of using a multivariate model approach for studying the factors that affect the adoption of rice technologies in Bolivia, (b) models the drivers on the extent of adoption of these technologies, and (c) derives policy implications and recommendations to better disseminate the rice technologies that would enhance the rice sector. Our results build upon previous findings by providing valuable insights for the Latin America and the Caribbean region. These kinds of analyses are virtually absent in LAC, as most studies with similar approaches highly concentrate on African cases.

Our research findings provide evidence of a significant joint correlation between the different agricultural technologies disseminated in Bolivia's rice sector. Likewise, 
Table 1. Rice (paddy) yield metrics for Latin America and the Caribbean, 1960-2018

\begin{tabular}{|c|c|c|c|c|c|c|c|}
\hline \multirow[b]{2}{*}{ Country } & \multicolumn{4}{|c|}{ Yield annual growth rate ${ }^{a}(\%)$} & \multicolumn{3}{|c|}{ Overall yield ${ }^{b}$} \\
\hline & $1961-1980$ & $1981-2000$ & $2001-2018$ & $1961-2018$ & $1961-2018$ & 2014 & 2018 \\
\hline Argentina & -0.29 & 2.15 & 0.92 & 1.43 & 5.23 & 6.50 & 6.90 \\
\hline Bolivia & 0.11 & 1.52 & 1.58 & 1.19 & 2.14 & 2.77 & 3.19 \\
\hline Brazil & -0.67 & 3.76 & 4.12 & 2.67 & 2.31 & 5.20 & 6.31 \\
\hline Colombia & 5.36 & 0.05 & 0.38 & 1.25 & 4.24 & 4.78 & 5.22 \\
\hline Costa Rica & 4.29 & 2.87 & 1.06 & 1.96 & 3.08 & 4.88 & 4.55 \\
\hline Dominican Republic & 3.26 & 0.68 & -2.30 & 1.23 & 3.99 & 3.26 & 3.26 \\
\hline Ecuador & 2.26 & 1.23 & 0.10 & 1.26 & 3.53 & 3.90 & 4.53 \\
\hline Guyana & 1.48 & 1.47 & -0.02 & 1.74 & 3.33 & 3.43 & 5.77 \\
\hline Nicaragua & 3.07 & -0.38 & 4.40 & 1.37 & 3.71 & 5.58 & 5.27 \\
\hline Panama & 2.76 & 1.65 & 0.73 & 2.09 & 2.14 & 3.26 & 3.34 \\
\hline Paraguay & -1.54 & 4.55 & 4.60 & 2.03 & 4.37 & 6.70 & 6.30 \\
\hline Peru & 0.39 & 1.89 & 1.10 & 1.39 & 6.14 & 7.60 & 8.12 \\
\hline Suriname & 1.93 & -0.33 & 1.57 & 0.57 & 3.88 & 4.43 & 4.87 \\
\hline Uruguay & 1.67 & 1.26 & 1.87 & 1.81 & 6.27 & 8.05 & 8.50 \\
\hline Venezuela & 4.21 & 3.85 & -1.02 & 2.08 & 3.79 & 5.11 & 4.16 \\
\hline
\end{tabular}

${ }^{a}$ The annual growth rates are calculated from the linear regression of log-yields over the years, i.e., this is $100^{\star} \beta$, where $\beta$ is coefficient from the linear regression log-(yield) $=\alpha+\beta^{\star}$ (year).

${ }^{\mathrm{b}}$ This is the simple average of yields for each country for the period 1960-2018, or for the specific years 2014 and 2018. Source: Elaborated by the authors based on FAOSTAT (2020).

evidence suggests that distance to technological diffusion centers, participation in producers' organizations, and access to extension services significantly affect the probability of adopting these technologies. We also argue that, to better target resource-poor farmers, there is a need to improve mechanisms to diffuse information on agricultural practices and promote better use of existing farmers' organizations to boost rice technology adoption and improve the overall conditions of rice-producing households in the country.

The article proceeds as follows: section two provides an overview of the Bolivian rice sector, while section three describes the data and empirical strategy used in the analysis. The final two sections, respectively, discuss the main results and summarize the conclusions and policy recommendations.

\section{Background: an overview of the Bolivian rice sector}

Rice is the third most consumed food in Bolivia (GRiSP 2013). It constitutes a primary source of dietary nutrients for its population and has become one of the major incomegenerating crops in its agricultural sector. However, the country has had considerably low historical yields compared with neighboring countries (Table 1), which has had implications for both consumers' and rice farming households' welfare. In countries 
such as Bolivia, Peru, and Ecuador, the rice-producing area is concentrated among farms with less than 10 hectares (ha). By 2007, Bolivia had 43,456 rice-growing households, for a total area of 179,162 ha (Ortiz and Soliz 2007). Only a small proportion of rice growers $(1,157)$ had irrigation systems on a total area of 18,000 ha. Most Bolivian rice production is under rainfed conditions. As expected, average yields differ significantly between rainfed and irrigated systems. On average, farmers in rainfed rice production reach $2 \mathrm{t} / \mathrm{ha}$, while a limited number of farmers using irrigation in their rice production reach more than $6 \mathrm{t} /$ ha (Ortiz and Soliz 2007).

Bolivian rice growers, and the broader agricultural sector, have faced adverse local market fluctuations and production challenges associated with a changing climate during the past few decades (Amemiya 2001; Andersen and Verner 2009; Winters 2012). Under this situation, and considering the role of rainfed production in the rice sector, access to appropriate crop technologies such as improved rice varieties has become more relevant, especially for small- and medium-scale farmers. Therefore, we focus our analysis on these two groups of rice growers. If engaged in adopting new technologies, they may have better chances to increase their rice productivity and, through higher yields and output quality, potentially have higher income and better livelihoods.

Farm-gate real prices for rice have steadily decreased during the last three decades in Bolivia and the main rice-producing countries in Latin America. Although this trend translates into cheaper food in urban areas, the decline in rice growers' prices has been higher in Bolivia. This has implied harsher conditions for small- and mediumscale farmers, namely those who have failed to decrease their production costs to a significant scale (i.e., low yields and declining prices have affected rice growers' expected returns). Therefore, there are incentives for these groups of farmers to adopt new technologies for improving food security and productivity in Bolivia (Salazar et al. 2015). However, at the same time, low crop profitability may discourage these farmers from investing in these technologies. This article seeks to answer this empirical question.

Research on agricultural technologies in Bolivia is limited due to the low priority of the farming sector and Bolivian governments' preference to support tin mining. Thus, agriculture has been encouraged only in valleys because of the natural constraints faced in other areas such as the highlands and tropical regions (Godoy, Morduch, and Bravo 1998). In recent decades, however, interest has increased in agriculture and in further developing and promoting the use of improved technologies (Ortiz and Soliz 2007). Rice is not a native crop to Latin America; farmers have only dealt with improved cultivars, ruling out the use of landraces or local varieties. However, Bolivian farmers have access to old and MIVs, introduced or officially released in the country at different times (Ortiz and Soliz 2007; Labarta et al. 2014). The dissemination of other rice technologies has also been spread out over different periods.

Latin America had not been part of the Green Revolution until the 1980s, when more international agricultural research centers were established worldwide (Dalrymple 1986). By 1983, Brazil, Colombia, Peru, Venezuela, and Cuba had become the region's largest rice-growing countries. At that time, little was known about highyielding rice varieties (HYVs) in Bolivia. Still, a rough estimated area on HYVs reported approximately 29,600 ha, mainly in upland and rainfed production systems. Besides this, the use of other agricultural inputs in rice production in the 1970s was reported to be limited (Dalrymple 1979).

By 1990, genetic resources for rice improvement in Bolivia had been virtually nonexistent (Taboada et al. 2005), and the production of this cereal had relied primarily on 
old varieties such as "Bluebonnet 50," introduced from the United States (Nguyen and Tran 2002). In 1997, the Centro de Investigación Agrícola Tropical, in the Santa Cruz region, started a rice genetic improvement program aimed at developing varieties better adapted to local soil conditions and rainfed production systems (Taboada et al. 2005). After ten years of work, they released the first two varieties developed for Bolivia. On the one hand, biofortified variety "Azucena" was made available to local farmers (HarvestPlus 2009) and, on the other hand, a collaboration with the Latin American Fund for Irrigated Rice (FLAR) developed variety "MAC 18." Six years later, two other varieties (SACIA FL-39 and SACIA FL-40) were released, thus increasing the number of modern improved rice varieties in the system, suitable for either manual, mechanized, or irrigated systems.

Finally, a key element to further understand Bolivia's rice production and technology adoption is Japanese-descendant farmers' historical role. Since the first wave of Japanese immigration into Bolivia during World War II, their influence over the Bolivian agricultural sector has been significant. Japanese-descendant farmers have led both in crop specialization and in the introduction of modern technologies in rice, soybean, and wheat in their settling-in areas. Two of the initial Japanese settlements (Okinawa and San Juan de Yapacaní) have become major technology dissemination points and crop commercialization centers in the Bolivian rice sector (Amemiya 2001). Thus, rice producers in the country could have benefited from being exposed to the Japanese-descendant centers that implemented and developed best crop production practices.

\section{Materials and methods}

Data

The data used for the analysis are a nationally representative sample of rice growers collected during 2014 by the International Center for Tropical Agriculture (CIAT) in collaboration with the Centro de Investigación Agrícola Tropical of Santa Cruz, Bolivia, across the three rice-producing regions in the country. The sampling design followed a multistage procedure distributed among 98 communities, consisting of 802 smalland medium-scale farmer households that provided the complete information required under the proposed model.

\section{Dependent variables}

As mentioned earlier, rice is not a native crop of Latin America, and all varieties grown by rice growers in Bolivia are genetically improved. However, the modern varieties released since 2004 currently occupy 45.6 percent of the total rice area. The other 54.4 percent of Bolivia's rice area uses old varieties mainly introduced from other countries before the foundation of the national rice breeding program. The rate of adoption of the different MIVs is shown in Table 2. Two MIVs dominate the preference of Bolivian rice growers: MAC 18, which resulted from the collaboration of the Bolivian rice program and FLAR, and IAC 101, which was bred by the rice breeding program of the State of São Paulo (Brazil), selected, and then released in Bolivia. These two varieties have adapted well to both irrigated and favored rainfed conditions in Bolivia. MAC 18 also offers a slightly higher quality of its grain, which is appreciated in the market. Despite being available to farmers for some time and expected to significantly improve 
Table 2. Adoption ${ }^{\text {a }}$ of modern improved rice varieties in Bolivia

\begin{tabular}{lccc}
\hline Variety & Overall adoption (\%) & Adoption within adopters (\%) & Year of release \\
\hline Amboró & 0.12 & 0.25 & 2004 \\
\hline Azucena & 0.12 & 0.25 & 2009 \\
\hline CAISY-50 & 0.24 & 0.51 & 2008 \\
\hline CICA-8 & 0.12 & 0.25 & 2009 \\
\hline Cristal & 3.79 & 8.08 & 2008 \\
\hline Esperanza & 0.24 & 0.51 & 2006 \\
\hline IAC 101 & 14.08 & 30.05 & 2005 \\
\hline MAC 18 & 25.09 & 53.54 & 2008 \\
\hline Paitití & 4.38 & 9.34 & 2004 \\
\hline Saavedra 27 & 0.36 & 0.76 & 2009 \\
\hline Saavedra 44 & 0.59 & 1.26 & 2009 \\
\hline Tapeque & 0.59 & 1.26 & 2004 \\
\hline
\end{tabular}

${ }^{\mathrm{a}}$ Farmers may adopt more than one rice variety; hence, the reported values of adoption do not add up to 100 percent. Source: Elaborated by the authors based on survey data.

productivity either in input-intensive (and mechanized) or manual production systems (Châtel et al. 2010), the rest of the modern varieties have not achieved a considerable rate of adoption. This is consistent with literature findings that productivity gains may not necessarily cover the additional costs from adopting new crop varieties, hence limiting their appeal to most farmers (Pretty, Ruben, and Thrupp 2002). Besides, materials that have long been used in local conditions are likely to be better adapted to their specific agroclimatic needs than their more recent competitors (Hoffman, Probst, and Christinck 2007).

Although rainfed systems dominate rice production in Bolivia, large machinery for planting and harvesting is available to rice growers. The possibility of mechanization among rainfed rice growers refers to the concept of favored rainfed systems (Lynch and Tasch 1981). Fertilization in rice production mainly relies on the use of mineral supplements with a range of combinations of nitrogen $(\mathrm{N})$, phosphorus $(\mathrm{P})$, and potassium $(\mathrm{K})$. The most available fertilizer formulations in local markets offer $\mathrm{N}, \mathrm{P}$, and $\mathrm{K}$ concentrations ranging from 21 to 46 percent, 20 to 45 percent, and 50 to 60 percent, respectively (Viruez and Taboada 2013). Chemical pest control is virtually a binary decision between products containing either cypermethrin or cyfluthrin to combat both the fall armyworm and Tibraca limbativentris. In contrast, most weed controls (herbicides) are made of bispyribac-sodium, imazapyr, imazapic, and penoxsulam.

We expect that rice growers in Bolivia have up to five technologies available that may increase their rice productivity compared with traditional rice practices, but this may also imply some degree of complementarity. These technologies, the adoption of MIVs, machinery used at seeding or harvesting, and the use of fertilizers, chemical pesticides, and herbicides on rice plots, constitute the dependent variables of our model. Our definition of "modern" improved variety considers varieties released in Bolivia since 2004 (eight years after establishing the rice improvement program). These are 


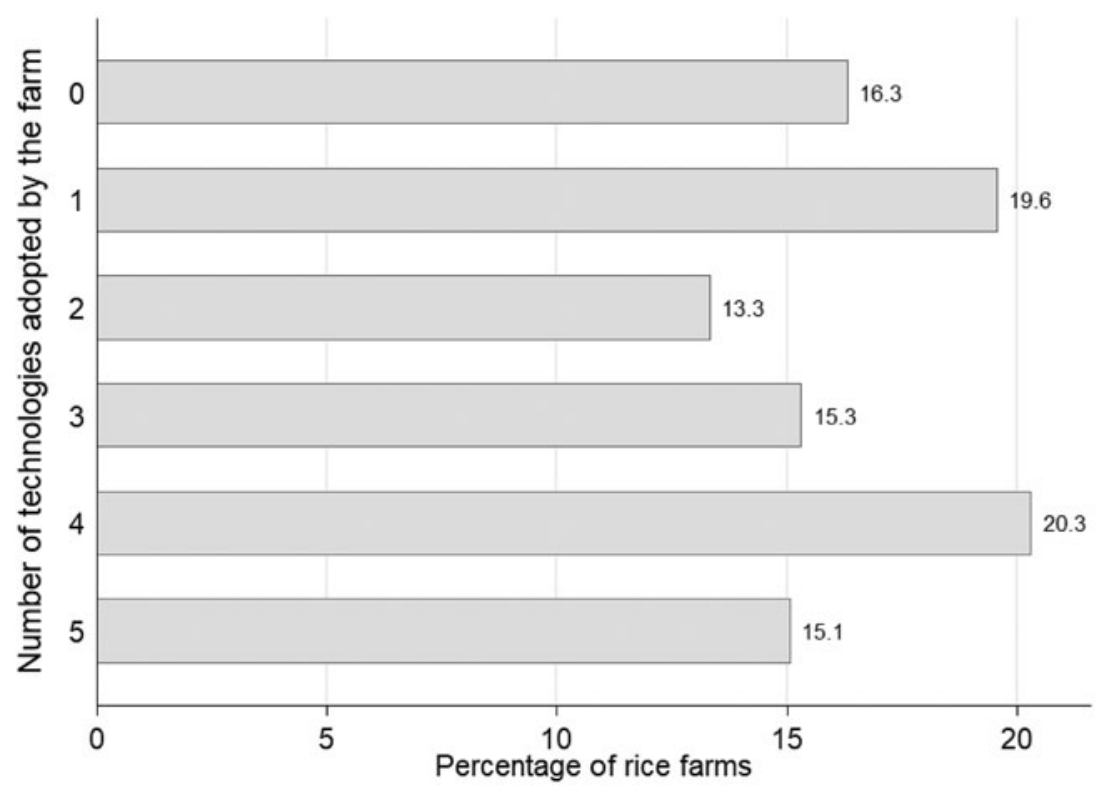

Figure 1. Number of Technologies Adopted by Interviewed Bolivian Rice Farmers. Source: Elaborated by the authors based on survey data.

up to 12 modern materials, including MAC 18, IAC 101, Azucena, SACIA FL-39, and SACIA FL-40. Other varieties, including Bluebonnet, are considered old types. Although these technologies could be expected as (nearly) perfect complements from an agronomic perspective, the observed extent of adoption (Figure 1) suggests that farms make only a partial adoption of such practices. Such a pattern is understandable for resource-limited households, whose decisions on production and consumption are highly interdependent. The latter follows the concept of nonseparability of decisions of agricultural households (Bardhan and Udry 1999). It is reasonable for these farms to adopt a part of an improvement package to gain at least a part of the potential benefits from adoption. Households may possess attributes that should be explored to understand better who are more likely to adopt each technology of interest. Also, it is worth noting that although these technologies may be labeled as input-intensive, they are not necessarily incompatible with future efforts in expanding the uptake of sustainable practices (Wainaina, Tongruksawattanab, and Qaima 2016).

\section{Econometric approach}

In this study, we consider a farmer household deciding whether or not to adopt a given technology. With no loss of generality, suppose that if household $i$ chooses to adopt the $m$ th technology, it reaches a utility of $V_{i m}^{1}$, while it would reach a utility of $V_{i m}^{0}$ otherwise. Therefore, they adopt the technology if and only if

$$
A_{i m}^{*}=V_{i m}^{1}-V_{i m}^{0}=x_{i}^{\prime} \beta_{m}+\varepsilon_{i m}>0,
$$


where the $\varepsilon_{i m}$ terms are unobservable shocks to the farmer utility for each $m$ technology, and $x_{i}$ are observed attributes of the household. Households are to choose whether to adopt each of the $m=1,2, \ldots, M$ nonexclusive technologies. While we do not observe $A_{i m}^{*}$ or $V_{i m}^{h}$, we do observe the adoption decision of each household as an index function, where $A_{i m}=1\left(A_{i m}^{*}>0\right)$. Relaxing the assumption that the unobservable shocks are independent, and assuming that they are jointly and normally distributed, leads to the multivariate Probit (MVP) regression model (Cameron and Trivedi 2005; Greene 2012), where

$$
A_{i m}=\operatorname{Pr}\left(A_{i m}^{*}>0\right)=\operatorname{Pr}\left(-\varepsilon_{i m}<x_{i}^{\prime} \beta_{m}\right)=\Phi_{M}^{m}\left(x_{i}^{\prime} \beta_{m}\right) .
$$

Let us model the joint probability of adoption for $M$ technologies as

$$
\operatorname{Pr}\left(A_{1}=1, A_{2}=1, \ldots, A_{M}=1\right)=\int_{-\infty}^{x^{\prime} \beta_{1}} \int_{-\infty}^{x^{\prime} \beta_{2}} \ldots \int_{-\infty}^{x^{\prime} \beta_{M}} \phi_{M}(\boldsymbol{t}, \Sigma) \mathrm{d} \boldsymbol{t},
$$

where $\phi_{M}$ is the standardized multivariate normal probability density function, and $\Sigma$ is the symmetric covariance matrix of the error vector $\varepsilon$, in which $\Sigma_{m n}=1$ if $m=n$, and $\Sigma_{m n}=\rho_{m n}=\rho_{n m}$ when $m \neq n$. Estimating the $M$-dimensional normal integrals is feasible by the Geweke, Hajivassiliou, and Keane (GHK) simulated-likelihood approach (Boersch-Supan and Hajivassiliou 1990; Cameron and Trivedi 2005; Greene 2012). The decision to model adoption at the household level ${ }^{1}$ follows that 95 percent of the interviewed households managed a single plot. Barely over 1 percent managed three or more plots. Thus, a household-level analysis does not conflict with similar studies as those of Donkoh, Azumah, and Awuni (2019), Gebremariam and Tesfaye (2018), and Zeng et al. (2020).

In addition to this, we model the extent of adoption as the number of technologies effectively implemented by the household (Wollni, Lee and Thies 2010), setting up an ordered Probit regression model that also resembles a random utility model. Here, farm household $i$ decides to adopt a total of $c_{i}$ technologies $\left(c_{i}=0,1,2,3,4,5\right)$ based on the utility

$$
U_{i}=h\left(x_{i}^{\prime} \theta\right)+\eta_{i}
$$

Although utility cannot be observed, as in the MVP setting, we observe the number of adopted technologies. We assume that a household adopts an additional technology if the utility of using it exceeds the utility of not adopting it. Moreover, the decision of extent of adopted technologies responds to utility levels defined across thresholds $\lambda$ such that

$$
\begin{gathered}
c_{i}=0, \quad \text { if } U_{i} \leq \lambda_{1}, \\
c_{i}=k, \quad \text { if } \lambda_{k}<U_{i} \leq \lambda_{k+1} \quad \text { for } k=1,2,3,4, \\
c_{i}=5, \quad \text { if } U_{i}>\lambda_{5} .
\end{gathered}
$$

\footnotetext{
${ }^{1}$ Additional results showed that the results hold when analyzing data at a plot level (Supplementary Tables S1-S3), but we decided to keep the analysis at a household level as this is the unit of interest for derived policy recommendations.
} 
Finally, if $\eta$ follows a normal distribution, then

$$
\begin{gathered}
\operatorname{Pr}\left(c_{i}=0 \mid x_{i}\right)=\Phi\left(\lambda_{1}-x_{i}^{\prime} \theta\right) \\
\operatorname{Pr}\left(c_{i}=k \mid x_{i}\right)=\Phi\left(\lambda_{k+1}-x_{i}^{\prime} \theta\right)-\Phi\left(\lambda_{k}-x_{i}^{\prime} \theta\right), \quad \text { if } k=1,2,3,4, \\
\operatorname{Pr}\left(c_{i}=5 \mid x_{i}\right)=1-\Phi\left(\lambda_{5}-x_{i}^{\prime} \theta\right) .
\end{gathered}
$$

The sign of $\theta$ coefficients in the ordered Probit model indicates the aggregate direction that covariates have in the number of technologies adopted by the household, i.e., whether the explanatory variable increases (decreases) the value of our latent variable $U$ (Cameron and Trivedi 2005). Nonetheless, marginal effects do not necessarily hold the same sign, as covariates may imply more (or less) likelihood of a point outcome.

\section{Explanatory variables and descriptive statistics}

Covariates used in this article (Table 3) are consistent with previous adoption studies on rice technologies and follow the underlying theoretical economic models that propose them (Saka et al. 2005; Usman, Ango, and Barau 2013; Yamano et al. 2016). We have included producers' associations and access to extension services to represent households' access to agricultural information. The model also includes variables related to human capital and income characteristics (of the household head) to control for differences in the dynamics followed toward the adoption decision. Geographic control of distance (in log-Geodesic scale) to San Juan de Yapacaní, one of the leading centers of rice technological diffusion, attempts to account for the level of exposure to the dissemination of rice technologies. Also, we use the farm's size as a proxy for its wealth endowment across all the decisions modeled, while yield priority represents households' varietal preference for higher-yielding varieties. Finally, we included department-fixed effects to account for the differences in labor availability and access to markets, since evidence suggests that changes in these attributes may increase the opportunity cost of technologies, making them less attractive or even nonaffordable (White, Labarta, and Leguía 2005). Santa Cruz has the most extensive availability in both labor and markets; thus, we choose it as the base category in both regression analyses.

Descriptive statistics of all the explanatory variables used in the analysis are summarized in Table 4, which compares average values between adopters and nonadopters of the five complementary technologies used in rice production. The distribution of adoption is somehow dissimilar across the different technological options. While roughly 65 percent of the rice growers use pesticide and weed controls, we found adoption levels of MIVs and machinery slightly under 50 percent of the interviewed households. On the other hand, fertilizer use is the lowest adopted rice technology (25 percent). Among adopters, the household heads tend to be slightly more educated and younger than nonadopters and, although female-headed households are unusual, they are marginally fewer among adopters. Households adopting the rice technologies have, on average, more alternative employment options and larger farm sizes. Adopters of technologies seem to have more access to agricultural extension and farmers' organizations. Statistical differences are significant between adopters and nonadopters, particularly for the household head level of education, farm size, belonging to a farmers' association, 
Table 3. Description of variables

\begin{tabular}{|c|c|}
\hline Variable & Definition \\
\hline $\begin{array}{l}\text { MIVs (modern improved } \\
\text { varieties) }\end{array}$ & $\begin{array}{l}\text { (1 = yes) Indicates whether the household uses modern improved } \\
\text { varieties in some of its plots. Modern varieties are set as those } \\
\text { disseminated on a large scale since } 2004 \text { (ten-year lag). }\end{array}$ \\
\hline Machinery & $\begin{array}{l}\text { (1=yes) Indicates whether the household uses large machinery } \\
\text { for planting or harvesting of rice plots. }\end{array}$ \\
\hline Fertilizer & ( $1=$ yes) If the household uses mineral fertilizers for rice plots. \\
\hline Pesticide & ( $1=$ yes $)$ If the household uses chemical pesticides for rice plots. \\
\hline Herbicide & ( 1 =yes) If the household uses chemical herbicides for rice plots. \\
\hline Yield priority & $\begin{array}{l}\text { (1 = yes) If the (expected) yield of a variety of rice is a priority } \\
\text { criterion for the farmer when choosing which variety to grow in } \\
\text { his/her field. } \\
\text { Expected sign: Positive since the search for more yield should } \\
\text { lead farmers to further adopt MIVs. }\end{array}$ \\
\hline Education & $\begin{array}{l}\text { Years of formal education of the household's head. } \\
\text { Expected relation: Positive, due to increased knowledge on } \\
\text { benefits from technology adoption. }\end{array}$ \\
\hline Age & $\begin{array}{l}\text { Age (in years) of the household's head. } \\
\text { Expected relation: Ambiguous; this happens because, although } \\
\text { it is related to more experience in crop management, it is also } \\
\text { related to more attachment to traditional technologies. }\end{array}$ \\
\hline Female household head & $\begin{array}{l}\text { (1 = yes) If the household's head is female. } \\
\text { Expected sign: Negative, related to a large portion of empirical } \\
\text { findings that demonstrate the less-favored conditions faced by } \\
\text { female-led farmer households. }\end{array}$ \\
\hline Alternative employment & $\begin{array}{l}\text { (1 = yes) If at least one of the members of the household relies on } \\
\text { a different income source besides rice production. } \\
\text { Expected sign: Negative, if households depending solely on rice } \\
\text { production have a special interest in adopting better } \\
\text { technologies with respect to the rest. }\end{array}$ \\
\hline Farm size & $\begin{array}{l}\text { In logarithmic form. Number of hectares available for agricultural } \\
\text { use. } \\
\text { Expected relation: Positive, because it is a proxy for farm/ } \\
\text { household income with the literature suggesting that better-off } \\
\text { households are more likely to adopt modern technologies. }\end{array}$ \\
\hline Association & $\begin{array}{l}\text { (1 = yes) If at least one household member belongs to a farmers' } \\
\text { association. } \\
\text { Expected sign: Positive, after considering feasible learning from } \\
\text { neighbors and other farmers. }\end{array}$ \\
\hline Extension services & $\begin{array}{l}\text { (1 = yes) If, during the past two years, at least one household } \\
\text { member attended a workshop or extension service specializing } \\
\text { in rice farming. } \\
\text { Expected sign: Positive, due to improved knowledge on } \\
\text { management. }\end{array}$ \\
\hline $\begin{array}{l}\text { Distance to San Juan de } \\
\text { Yapacaní (SJY) }\end{array}$ & $\begin{array}{l}\text { In logarithmic form. Geodesic distance from the farm's location to } \\
\text { San Juan de Yapacaní cooperative CAISY. } \\
\text { Expected relation: Negative, since the more the distance to } \\
\text { improved technology dissemination and feasible spillover } \\
\text { effects, the less likely to adopt such technologies. }\end{array}$ \\
\hline
\end{tabular}

Source: Elaborated by the authors. 
Table 4. Descriptive statistics

\begin{tabular}{|c|c|c|c|c|c|c|c|c|c|c|c|}
\hline \multirow{2}{*}{\multicolumn{2}{|c|}{$\begin{array}{l}\text { Technology } \\
\text { Overall adoption rate }\end{array}$}} & \multicolumn{2}{|c|}{ MIVs } & \multicolumn{2}{|c|}{ Machinery } & \multicolumn{2}{|c|}{ Fertilizer } & \multicolumn{2}{|c|}{ Pest control } & \multicolumn{2}{|c|}{ Herbicide } \\
\hline & & \multicolumn{2}{|c|}{$45.64 \%$} & \multicolumn{2}{|c|}{$49.13 \%$} & \multicolumn{2}{|c|}{$25.56 \%$} & \multicolumn{2}{|c|}{$65.84 \%$} & \multicolumn{2}{|c|}{$62.84 \%$} \\
\hline Variables & $\begin{array}{l}\text { Overall } \\
\text { Mean }^{c}\end{array}$ & $\begin{array}{l}\text { Nonadopter } \\
\text { Mean }\end{array}$ & $\begin{array}{l}\text { Adopter }^{\mathrm{b}} \\
\text { Mean }\end{array}$ & $\begin{array}{l}\text { Nonadopter } \\
\text { Mean }\end{array}$ & $\begin{array}{l}\text { Adopter } \\
\text { Mean }\end{array}$ & $\begin{array}{l}\text { Nonadopter } \\
\text { Mean }\end{array}$ & $\begin{array}{l}\text { Adopter } \\
\text { Mean }\end{array}$ & $\begin{array}{l}\text { Nonadopter } \\
\text { Mean }\end{array}$ & $\begin{array}{l}\text { Adopter } \\
\text { Mean }\end{array}$ & $\begin{array}{l}\text { Nonadopter } \\
\text { Mean }\end{array}$ & $\begin{array}{l}\text { Adopter } \\
\text { Mean }\end{array}$ \\
\hline Yield priority ${ }^{1}(\%)$ & 70.8 & 69.7 & 72.1 & - & - & - & - & - & - & - & - \\
\hline Education (years) & 6.10 & 5.36 & $6.98^{\star \star \star}$ & 5.30 & $6.93^{\star \star \star}$ & 5.86 & $6.80^{\star \star}$ & 5.51 & $6.40^{\star \star}$ & 5.31 & $6.56^{\star \star \star}$ \\
\hline Age (years) & 45.95 & 46.65 & $45.12^{\star}$ & 46.24 & 45.66 & 46.23 & 45.14 & 48.14 & $44.82^{\star \star \star}$ & 47.04 & $45.31^{*}$ \\
\hline Females (\%) & 3.7 & 3.9 & 3.6 & 4.2 & 3.3 & 4.2 & 2.4 & 4.7 & 3.2 & 5.4 & $2.8^{*}$ \\
\hline Alt. employment (\%) & 48.6 & 46.6 & 51.1 & 49.0 & 48.2 & 47.6 & 51.7 & 49.3 & 48.3 & 48.0 & 49.0 \\
\hline Farm size (log) (ha) & 2.93 & 2.55 & $3.38^{\star \star \star}$ & 2.12 & $3.76^{\star \star \star}$ & 2.64 & $3.76^{\star \star \star}$ & 2.09 & $3.36^{\star \star \star}$ & 1.87 & $3.55^{\star \star \star}$ \\
\hline Association (\%) & 15.5 & 8.0 & $24.3^{\star \star \star}$ & 7.6 & $23.6^{\star \star \star}$ & 12.2 & $24.9^{\star \star \star}$ & 9.5 & $18.6^{\star \star \star}$ & 6.7 & $20.6^{\star \star \star}$ \\
\hline Extension (\%) & 18.1 & 13.3 & $23.8^{\star \star \star}$ & 9.8 & $26.6^{\star \star \star}$ & 14.6 & $28.3^{\star \star \star}$ & 12.0 & $21.2^{\star \star \star}$ & 10.1 & $22.8^{\star \star \star}$ \\
\hline Distance to SJY (log) & 4.00 & 4.21 & $3.74^{\star \star \star}$ & 4.65 & $3.33^{\star \star \star}$ & 4.18 & $3.45^{\star \star \star}$ & 4.67 & $3.65^{\star \star \star}$ & 4.83 & $3.51^{\star \star \star}$ \\
\hline (Log-) Distance to SJY (km) & 90.1 & 106.37 & $72.28^{\star \star \star}$ & 128.68 & $51.6^{\star \star \star}$ & 103.31 & $54.4^{\star \star \star}$ & 136.2 & $67.27^{\star \star \star}$ & 145.9 & $58.24^{\star \star \star}$ \\
\hline Beni (\%) & 28.8 & 35.8 & $20.5^{\star \star \star}$ & 46.8 & $10.2^{\star \star \star}$ & 35.3 & $9.8^{\star \star \star}$ & 50.7 & $17.4^{\star \star \star}$ & 57.7 & $11.7^{\star \star \star}$ \\
\hline Cochabamba (\%) & 10.1 & 8.3 & $12.3^{*}$ & 13.2 & $6.9^{\star \star \star}$ & 11.4 & $6.3^{\star \star}$ & 9.9 & 10.2 & 13.8 & $7.9^{\star \star \star}$ \\
\hline Santa Cruz (\%) & 61.1 & 55.9 & $67.21^{\star \star \star}$ & 39.9 & $82.9^{\star \star \star}$ & 53.26 & $83.9^{\star \star \star}$ & 39.41 & $72.34^{\star \star \star}$ & 28.5 & $80.35^{\star \star \star}$ \\
\hline
\end{tabular}

Y Yield priority is disaggregated only for MIVs, following the rationale in Table 2

${ }^{a}$ Nonadopters, badopters, and ' reporting means and percentages for continuous and binary variables, respectively.

Reporting significance of variable's mean difference between adopters and nonadopters of each technology: ${ }^{* \star *} p<0.01,{ }^{\star *} p<0.05$, ${ }^{\star} p<0.1$.

Source: Elaborated by the authors based on survey data. 
access to extension services, and the distance to the main technology diffusion center (San Juan de Yapacaní). Notice how the difference of average distance to diffusion centers can be a scale factor of two when comparing adopters and nonadopters. In any case, relying on alternative income sources is an evenly distributed condition between adopters and nonadopters. On the other hand, having a female household head reports only a statistical difference when comparing adopters and nonadopters of herbicides.

\section{Results}

Checking the sample unconditional and conditional probabilities of technology adoption (Table 5), it is clear that there exists a strong complementarity among these five practices. As an example, consider the unconditional probabilities of mechanization (50.8 percent), fertilization (25.3 percent), use of pesticides (65.4 percent), and herbicides (62.8 percent), that rapidly increase by $19.4,11.3,9.6$, and 13.2 percent points, respectively, given once the household adopts modern improved rice varieties. The single condition that appears most increase other probabilities of adoption is inorganic fertilizers, which raises the likelihood of using MIV to 65 percent, machinery to 87.4 percent, and both pesticide and herbicides to a solid 97.2 percent. Another interpretation is that farms that use fertilization (less recurrent practice) are more likely to be those who have already implemented other technologies, hence use this final technology to exploit their productive capabilities further. Notice how the probability of adoption of other technologies systematically increases (sometimes over 95 percent) in any combination of conditions that have fertilization as given. Also, the systematic increase in the probability of adopting MIVs given the presence of a mechanized system (20 percent point) may suggest that modern varieties are more common among farm households with higher initial endowments mechanization intensive. In general, without further controls, these agricultural practices give a signal of being strongly, but not perfectly, correlated.

Our econometric analysis provides evidence that the decisions to adopt complementary technologies in rice production in Bolivia are correlated, justifying the use of an MVP model to understand the factors that explain these decisions. Table 6 presents the partial correlations across all technologies included in the analysis and the joint significance test, suggesting that the individual adoption of rice technologies is affected by the other complementary technologies' decisions. Not controlling for the correlation between individual adoption decisions and their unobservables would bias the covariates' coefficient estimation. When estimating separate Probit models for each technology, ${ }^{2}$ we find coefficients that are slightly larger in absolute value and more likely to be statistically significant. Thus, assuming independent normal distributions for the errors rather than a joint distribution may mean a potential distortion in the magnitude of the detected partial correlations and an augmented probability of incurring in type I error when defining the adoption determinants.

After controlling for the verified multivariate correlation of the decisions to adopt complementary rice technologies and regional (department-level) fixed effects, we present the results of the determinants of joint adoption in Table 7. We found that farm size is the only explanatory variable that can explain the adoption of all the technologies considered in the analysis. The greater the farm size, the higher the likelihood of Bolivian rice growers adopting the available rice technologies. This finding is consistent

\footnotetext{
${ }^{2}$ Not reported here. See Supplementary Table S4.
} 
Table 5. Sample unconditional and conditional probabilities of technology adoption

\begin{tabular}{|c|c|c|c|c|c|}
\hline Condition & MIV & Machinery & Fertilization & $\begin{array}{c}\text { Pest } \\
\text { control }\end{array}$ & Herbicide \\
\hline Unconditional & 0.45 & 0.49 & 0.25 & 0.66 & 0.63 \\
\hline$Y_{V}=1$ & 1 & $0.7^{\star \star \star}$ & $0.37^{\star \star \star}$ & $0.75^{\star \star \star}$ & $0.76^{\star \star \star}$ \\
\hline$Y_{M}=1$ & $0.65^{\star \star \star}$ & 1 & $0.44^{\star \star \star}$ & $0.85^{\star \star \star}$ & $0.93^{\star \star \star}$ \\
\hline$Y_{F}=1$ & $0.68^{\star \star \star}$ & $0.87^{\star \star \star}$ & 1 & $0.97^{\star \star \star}$ & $0.97^{\star \star \star}$ \\
\hline$Y_{P}=1$ & $0.54^{\star \star \star}$ & $0.66^{\star \star \star}$ & $0.38^{\star \star \star}$ & 1 & $0.81^{\star \star \star}$ \\
\hline$Y_{\mathrm{H}}=1$ & $0.57^{\star \star \star}$ & $0.75^{\star \star \star}$ & $0.39^{\star \star \star}$ & $0.85^{\star \star \star}$ & 1 \\
\hline$Y_{V}=1, Y_{M}=1$ & 1 & 1 & $0.48^{\star \star \star}$ & $0.88^{\star \star \star}$ & $0.95^{\star \star \star}$ \\
\hline$Y_{\mathrm{V}}=1, Y_{\mathrm{F}}=1$ & 1 & $0.92^{\star \star \star}$ & 1 & $0.98^{\star \star \star}$ & $0.97^{\star \star \star}$ \\
\hline$Y_{\mathrm{V}}=1, Y_{\mathrm{P}}=1$ & 1 & $0.82^{\star \star \star}$ & $0.48^{\star \star \star}$ & 1 & $0.9^{\star \star \star}$ \\
\hline$Y_{\mathrm{V}}=1, Y_{\mathrm{H}}=1$ & 1 & $0.88^{\star \star \star}$ & $0.47^{\star \star \star}$ & $0.88^{\star \star \star}$ & 1 \\
\hline$Y_{M}=1, Y_{F}=1$ & $0.72^{\star \star \star}$ & 1 & 1 & $0.98^{\star \star \star}$ & $0.99^{\star \star \star}$ \\
\hline$Y_{M}=1, Y_{P}=1$ & $0.67^{\star \star \star}$ & 1 & $0.5^{\star \star \star}$ & 1 & $0.97^{\star \star \star}$ \\
\hline$Y_{M}=1, Y_{H}=1$ & $0.66^{\star \star \star}$ & 1 & $0.46^{\star \star \star}$ & $0.88^{\star \star \star}$ & 1 \\
\hline$Y_{F}=1, Y_{P}=1$ & $0.68^{\star \star \star}$ & $0.88^{\star \star \star}$ & 1 & 1 & $0.98^{\star \star \star}$ \\
\hline$Y_{\mathrm{F}}=1, Y_{\mathrm{H}}=1$ & $0.68^{\star \star \star}$ & $0.89^{\star \star \star}$ & 1 & $0.98^{\star \star \star}$ & 1 \\
\hline$Y_{P}=1, Y_{H}=1$ & $0.59^{\star \star \star}$ & $0.78^{\star \star \star}$ & $0.45^{\star \star \star}$ & 1 & 1 \\
\hline$Y_{\mathrm{V}}=1, Y_{\mathrm{M}}=1, Y_{\mathrm{F}}=1$ & 1 & 1 & 1 & $0.99^{\star \star \star}$ & $0.99^{\star \star \star}$ \\
\hline$Y_{V}=1, Y_{M}=1, Y_{P}=1$ & 1 & 1 & $0.54^{\star \star \star}$ & 1 & $0.97^{\star \star \star}$ \\
\hline$Y_{V}=1, Y_{M}=1, Y_{H}=1$ & 1 & 1 & $0.5^{\star \star \star}$ & $0.89^{\star \star \star}$ & 1 \\
\hline$Y_{V}=1, Y_{F}=1, Y_{P}=1$ & 1 & $0.93^{\star \star \star}$ & 1 & 1 & $0.98^{\star \star \star}$ \\
\hline$Y_{V}=1, Y_{F}=1, Y_{H}=1$ & 1 & $0.94^{\star \star \star}$ & 1 & $0.99^{\star \star \star}$ & 1 \\
\hline$Y_{\mathrm{V}}=1, Y_{\mathrm{P}}=1, Y_{\mathrm{H}}=1$ & 1 & $0.89^{\star \star \star}$ & $0.52^{\star \star \star}$ & 1 & 1 \\
\hline$Y_{M}=1, Y_{F}=1, Y_{P}=1$ & $0.72^{\star \star \star}$ & 1 & 1 & 1 & $0.99^{\star \star \star}$ \\
\hline$Y_{M}=1, Y_{F}=1, Y_{H}=1$ & $0.71^{\star \star \star}$ & 1 & 1 & $0.98^{\star \star \star}$ & 1 \\
\hline$Y_{M}=1, Y_{P}=1, Y_{H}=1$ & $0.67^{\star \star \star}$ & 1 & $0.51^{\star \star \star}$ & 1 & 1 \\
\hline$Y_{\mathrm{F}}=1, Y_{\mathrm{P}}=1, Y_{\mathrm{H}}=1$ & $0.68^{\star \star \star}$ & $0.89^{\star \star \star}$ & 1 & 1 & 1 \\
\hline $\begin{array}{l}Y_{V}=1, Y_{M}=1, Y_{F}=1 \\
Y_{P}=1\end{array}$ & 1 & 1 & 1 & 1 & $0.98^{\star \star \star}$ \\
\hline $\begin{array}{l}Y_{V}=1, Y_{M}=1, Y_{F}=1 \\
Y_{H}=1\end{array}$ & 1 & 1 & 1 & $0.98^{\star \star \star}$ & 1 \\
\hline $\begin{array}{c}Y_{V}=1, Y_{M}=1, Y_{P}=1 \\
Y_{H}=1\end{array}$ & 1 & 1 & $0.55^{\star \star \star}$ & 1 & 1 \\
\hline $\begin{array}{l}Y_{V}=1, Y_{F}=1, Y_{P}=1 \\
Y_{H}=1\end{array}$ & 1 & $0.94^{\star \star \star}$ & 1 & 1 & 1 \\
\hline
\end{tabular}


Table 5. (Continued.)

\begin{tabular}{lllllc}
\hline Condition & MIV & Machinery & Fertilization & $\begin{array}{c}\text { Pest } \\
\text { control }\end{array}$ & Herbicide \\
\hline $\begin{array}{c}Y_{\mathrm{M}}=1, Y_{\mathrm{F}}=1, Y_{\mathrm{P}}=1, \\
Y_{\mathrm{H}}=1\end{array}$ & $0.72^{\star \star \star}$ & 1 & 1 & 1 & 1 \\
\hline
\end{tabular}

$Y_{\mathrm{V}}, Y_{\mathrm{M}}, Y_{\mathrm{F}}, Y_{\mathrm{P}}$, and $Y_{\mathrm{H}}$ are index variables for the adoption status (1=yes) for modern improved varieties, machinery, fertilization, pest control, and herbicides, respectively.

${ }^{\star \star *} p<0.01,{ }^{\star *} p<0.05,{ }^{*} p<0.1$, compared with the unconditional probability of adopting the technology. Source: Elaborated by the authors based on survey data.

Table 6. Multivariate Probit correlation results

\begin{tabular}{lcccc}
\hline$\rho_{21}$ & $\rho_{31}$ & $\rho_{41}$ & $\rho_{51}$ & $\rho_{32}$ \\
\hline $0.463^{\star \star \star}$ & $0.238^{\star \star \star}$ & 0.140 & $0.204^{\star}$ & $0.609^{\star \star \star}$ \\
\hline$(0.10)$ & $(0.08)$ & $(0.10)$ & $(0.10)$ & $(0.09)$ \\
\hline$\rho_{42}$ & $\rho_{52}$ & $\rho_{43}$ & $\rho_{53}$ & $\rho_{54}$ \\
\hline $0.426^{\star \star \star}$ & $0.909^{\star \star \star}$ & $0.776^{\star \star \star}$ & $0.704^{\star \star \star}$ & $0.623^{\star \star \star}$ \\
\hline$(0.09)$ & $(0.12)$ & $(0.11)$ & $(0.11)$ & $(0.10)$ \\
\hline
\end{tabular}

Joint significance LR test: $\operatorname{chi}^{2}(10)=379.43, \mathrm{p}$-value $=0.00$.

Robust standard errors in parentheses. ${ }^{\star \star \star} p<0.01,{ }^{\star \star} p<0.05,{ }^{*} p<0.1$.

Note: $\rho_{i j}$ defines the correlation between technologies $i$ and $j$, with values meaning (1) MIVs, (2) machinery, (3) fertilizer, (4) pesticide, and (5) herbicide.

Source: Elaborated by the authors based on survey data.

with other studies implemented in Latin America's rice sector (Suarez 2014; Marin et al. 2018) and further studies on agricultural technology adoption more broadly in different regions (Walker and Alwang 2015; Yamano et al. 2016). A plausible explanation of this result is that larger farmers tend to have better conditions and more resources to cope with the risks of incorporating new technology in their current crop management. In Bolivia, it has been reported that farmers with better socioeconomic conditions are more likely to have better practices in their agricultural systems (Ortiz and Soliz 2007; Salazar et al. 2015).

Two other factors were relevant in explaining farmers' decisions to adopt three out of the five rice technologies. Being part of a farmer association significantly increases the probability of adopting MIVs, machinery, and herbicides. This finding can be explained by the fact that most programs delivering agricultural inputs in Bolivia use existing organizations for reaching and distribution purposes. Likewise, having access to agricultural extension services was found to increase the probability of adopting machinery and fertilizer. Although extension services have had limited coverage in Bolivia, both public and NGO extension programs have tried to meet local farmers' demands and make available these agricultural technologies (FAO 2011). This has been a strong argument for organizations such as the Centro de Investigación Agrícola Tropical in designing new strategies to overcome current restrictions on farmers in specific regions to access known rice technologies.

As expected, we found a negative relationship between distance to the main center of rice technological dissemination in San Juan de Yapacaní and the probability of 
Table 7. Multivariate Probit regression results on technology adoption

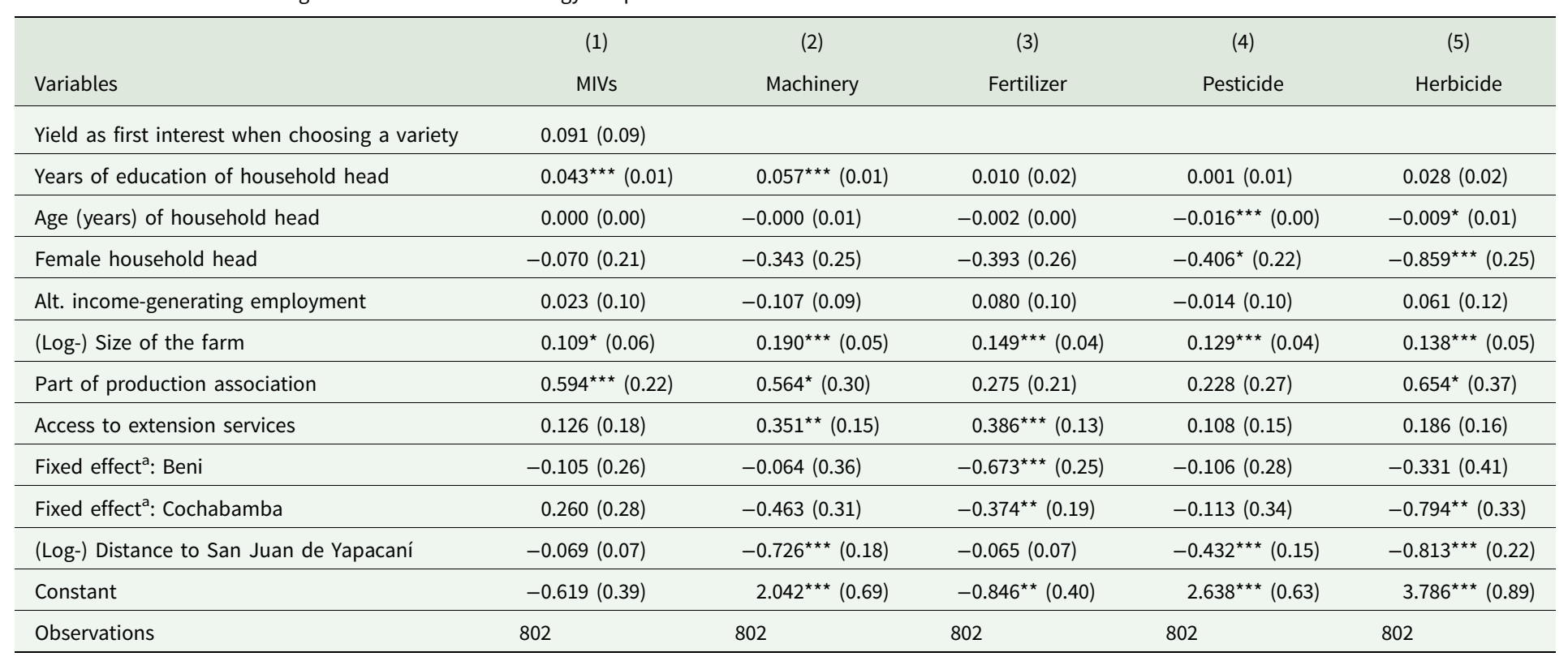

${ }^{\mathrm{a} B a s e}$ category is Santa Cruz.

Robust standard errors in parentheses. ${ }^{\star \star \star} p<0.01,{ }^{\star \star} p<0.05,{ }^{\star} p<0.1$.

Source: Elaborated by the authors based on survey data. 
adopting rice technologies; however, we found significant effects only on adopting machinery, pesticides, and herbicides. This hypothesis, first developed by Amemiya (2001), has been largely confirmed in the literature. Furthermore, Taboada et al. (2005) has highlighted the relevance of the Japanese-Bolivian dissemination centers for Bolivia's rice production. For the case of adopting MIVs and fertilizer, it could be argued that these specialized technologies may show asymmetries due to geographic limitations. The latter could be because those farm households near Japanese-Bolivian farmers observe the technological measures taken by those farmers, which include relatively high-cost inputs such as machinery and chemical pesticides and herbicides.

Nonetheless, recent studies among rural communities in Bolivia show that information technology may substantially enhance rural livelihoods (Gigler 2015) by helping traditionally marginalized communities make better-informed decisions. However, such impacts may heavily rely on strong intermediate actors (in our case, extension services and associations), who can further help farmers assimilate technical information and recommendations provided by research entities. Despite such findings, increasing availability of information technologies in remote areas means a need for future studies with updated data that test whether the effect of proximity to dissemination centers still holds.

Other factors that showed significant effects on rice technologies' adoption decisions are the household head's age, education level, and gender. An additional year in the household head's education significantly affects the probability of adopting MIVs and machinery. Likewise, we found that older farm households and female-headed households are less likely to adopt chemical pest and weed controls. These findings are consistent with previous results reported in rice in Africa (Saka et al. 2005; Usman, Ango, and Barau 2013) and Latin America (Suarez 2014), as well as for other crops and practices in developing countries (Kassie et al. 2013; Teklewold, Kassie, and Shiferaw 2013; Manda et al. 2016; Gebremariam and Tesfaye, 2018; Kanyenji et al. 2020).

We summarize the results from the ordered Probit model of the number of technologies adopted by Bolivian rice farmers in Table 8 . One of the first striking results is the systematic change of sign for all marginal effects when crossing the barrier of two or fewer technologies to three or more technologies. On average, farms whose household heads are more educated are slightly over 1 percent more likely to adopt three or more technologies. Also, larger farms (i.e., related to higher financial endowments) are about 8 percent more likely to adopt more technologies. Also, farming households who are part of a production association or have access to extension services are 20 and 12 percent more likely, respectively, to be among those with higher levels of adoption.

On the other hand, farms that are farther away from the national dissemination center are around 8 percent more likely to adopt two or fewer technologies. Furthermore, households located in Beni and Cochabamba will have about 23 and 13 percent more probability, respectively, to find themselves in the lower range of technology adoption. Also, farms whose household head is female are 17 percent less likely to reach upper adoption levels. Off-farm means of income seem to have no effect on farmers being either in the upper or lower adoption levels. The only apparent inconsistent result is the null effect of the household head's age, but this may be a consequence of the small (although significant) correlation it holds with only two technologies, namely pesticides and herbicides. These additional findings corroborate the determinants highlighted in the multivariate model and extend them to the total amount of adoption. 
Table 8. Ordered Probit regression and marginal effects on the number of adopted technologies

\begin{tabular}{|c|c|c|c|c|c|c|c|}
\hline & (1) & $(2)$ & (3) & (4) & (5) & (6) & (7) \\
\hline Variables & Coeff. & $P(k=0)$ & $P(k=1)$ & $P(k=2)$ & $P(k=3)$ & $P(k=4)$ & $P(k=5)$ \\
\hline $\begin{array}{l}\text { Years of educ. of household } \\
\text { head }\end{array}$ & $0.03^{\star \star \star}(0.01)$ & $-0.01^{\star \star \star}(0.00)$ & $-0.01^{\star \star \star}(0.00)$ & $-0.00^{\star \star \star}(0.00)$ & $0.00^{\star \star \star}(0.00)$ & $0.01^{\star \star \star}(0.00)$ & $0.00^{\star \star \star}(0.00)$ \\
\hline Age (years) of household head & $-0.00(0.00)$ & $0.00(0.00)$ & $0.00(0.00)$ & $0.00(0.00)$ & $-0.00(0.00)$ & $-0.00(0.00)$ & $-0.00(0.00)$ \\
\hline Female household head & $-0.44^{\star \star}(0.20)$ & $0.09^{\star}(0.05)$ & $0.07^{\star \star \star}(0.03)$ & $0.00(0.01)$ & $-0.04^{\star}(0.02)$ & $-0.08^{\star \star}(0.03)$ & $-0.05^{\star \star \star}(0.02)$ \\
\hline $\begin{array}{l}\text { Alt. income-generating } \\
\text { employment }\end{array}$ & $0.02(0.08)$ & $-0.00(0.01)$ & $-0.00(0.01)$ & $-0.00(0.00)$ & $0.00(0.00)$ & $0.00(0.01)$ & $0.00(0.01)$ \\
\hline (Log-) Size of the farm & $0.19^{\star \star \star}(0.03)$ & $-0.03^{\star \star \star}(0.01)$ & $-0.04^{\star \star \star}(0.01)$ & $-0.01^{\star \star \star}(0.00)$ & $0.01^{\star \star \star}(0.00)$ & $0.04^{\star \star \star}(0.01)$ & $0.03^{\star \star \star}(0.00)$ \\
\hline Part of production association & $0.51^{\star \star \star}(0.11)$ & $-0.07^{\star \star \star}(0.01)$ & $-0.09^{\star \star \star}(0.02)$ & $-0.04^{\star \star \star}(0.01)$ & $0.01^{\star}(0.01)$ & $0.09^{\star \star \star}(0.02)$ & $0.10^{\star \star \star}(0.03)$ \\
\hline Access to extension services & $0.29^{\star \star \star}(0.11)$ & $-0.04^{\star \star \star}(0.01)$ & $-0.06^{\star \star \star}(0.02)$ & $-0.02^{\star \star}(0.01)$ & $0.01^{\star \star \star}(0.00)$ & $0.05^{\star \star \star}(0.02)$ & $0.05^{\star \star}(0.02)$ \\
\hline Fixed effect ${ }^{a}$ : Beni & $-0.61^{\star \star \star}(0.12)$ & $0.12^{\star \star \star}(0.03)$ & $0.10^{\star \star \star}(0.02)$ & $0.01^{\star \star \star}(0.01)$ & $-0.05^{\star \star \star}(0.01)$ & $-0.11^{\star \star \star}(0.02)$ & $-0.08^{\star \star \star}(0.01)$ \\
\hline Fixed effect ${ }^{\mathrm{a}}$ : Cochabamba & $-0.32^{\star \star}(0.13)$ & $0.06^{\star \star}(0.03)$ & $0.06^{\star \star \star}(0.02)$ & $0.01^{\star \star \star}(0.00)$ & $-0.03^{\star}(0.01)$ & $-0.06^{\star \star}(0.02)$ & $-0.04^{\star \star \star}(0.01)$ \\
\hline $\begin{array}{l}\text { (Log-) Distance to San Juan de } \\
\text { Yapacaní }\end{array}$ & $-0.22^{\star \star \star}(0.04)$ & $0.04^{\star \star \star}(0.01)$ & $0.04^{\star \star \star}(0.01)$ & $0.01^{\star \star \star}(0.00)$ & $-0.01^{\star \star \star}(0.00)$ & $-0.04^{\star \star \star}(0.01)$ & $-0.03^{\star \star \star}(0.01)$ \\
\hline$\lambda_{1}$ & $-1.75^{\star \star \star}(0.25)$ & & & & & & \\
\hline$\lambda_{2}$ & $-0.92^{\star \star \star}(0.25)$ & & & & & & \\
\hline$\lambda_{3}$ & $-0.42^{\star}(0.25)$ & & & & & & \\
\hline$\lambda_{4}$ & $0.13(0.25)$ & & & & & & \\
\hline$\lambda_{5}$ & $0.96^{\star \star \star}(0.25)$ & & & & & & \\
\hline Observations & 802 & 802 & 802 & 802 & 802 & 802 & 802 \\
\hline
\end{tabular}

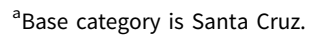

Joint significance LR test: $\operatorname{chi}^{2}(10)=394.33$, p-value $=0.00$

Robust standard errors in parentheses. ${ }^{\star \star \star} p<0.01,{ }^{\star \star} p<0.05,{ }^{*} p<0.1$

Source: Elaborated by the authors based on survey data. 


\section{Conclusions}

Despite the importance of rice in Bolivia, this cereal crop production remains constrained and shows low yields. Our results show that Bolivian rice growers have adopted most of the five agricultural technologies studied (MIVs, machinery, fertilizer, pesticide, and herbicide), although at different rates. However, this adoption has not translated into higher rice yields that better position Bolivia's productivity among other LAC countries. Our results reveal strong complementarities among rice-producing technologies in Bolivia, which must be considered when exploring their adoption determinants. This further reinforces previous findings that highlight the caveats of assuming independent decisions on productive technologies adoption-it may result in biased estimates and increased likelihood of type I error at identifying specific determinants of adoption.

Modern varieties have reached a rate of adoption of 45.6 percent, which is a good outcome for the nascent rice breeding program in the country. The materials MAC 18 and IAC 101 are the most used ones because of their productivity and good grain quality. Yet again, the adoption of these varieties seems to have not influenced rice productivity. This could be associated with the relatively low use of fertilizer ( 25 percent), traditionally referred to as a perfect complement of improved varieties. Although MIVs are suitable for manual and mechanized systems, their adoption appears to be more concentrated among mechanized systems. Hence, the potential for improvement for the overall rice productive system in Bolivia may have not yet been reached.

Our analysis particularly highlights the critical role of belonging to a farmer organization, having access to agricultural extension, and proximity to San Juan de Yapacaní (the main technological dissemination area for rice in Bolivia), in increasing the likelihood of adopting improved technologies in rice production. These determinants hold not only for the adoption decision of each technology but also for the extent of adoption of these technologies among Bolivian rice farmers. Farms located in areas with higher availability of labor and large markets (namely, the Department of Santa Cruz) are more likely to adopt a larger number of technologies.

Therefore, the weakness of the national extension system can also explain part of the low rice yields despite the documented adoption of rice technologies. Our results also support strategies that try to build technology dissemination efforts on the country's existing strengths. Bolivia is a country that has traditionally relied on local farmer organizations, and these should continue to be a critical mechanism for further technology dissemination. Likewise, government policy should further promote and expand the use of existing technology diffusion centers such as San Juan de Yapacaní. This has proven to be an efficient farmer-to-farmer knowledge dissemination mechanism, especially among small and medium rice growers for whom low rice yields are concentrated. Finally, this study also provides evidence that technology adoption in developing countries seems biased toward larger farmers, who respond better to using existing improved technologies. Governments and donors should concentrate efforts on identifying strategies to target resource-poor farmers better, so they can gain access to improved technologies, which may result in an overall increase in rice productivity and livelihood conditions.

Supplementary material. The supplementary material for this article can be found at https://oi.org/10. 1017/age.2021.9.

Acknowledgments. We want to thank Victor Zuluaga, Alexander Buriticá, Javier Castro, and the 8th Bolivian Conference of Development Economics participants for the comments provided to earlier versions of the manuscript. Also, we thank the comments and suggestions from two anonymous referees and the Editor, Dr. Richard Melstrom, which greatly benefited the article. 
Funding statement. This study is a result of the project Adoption study of rice varieties in Bolivia led by the Alliance of Bioversity International and CIAT, made possible with support from the CGIAR Global Research Program on Rice and HarvestPlus. HarvestPlus' principal donors are the UK Government; the Bill \& Melinda Gates Foundation; the US Government's Feed the Future initiative; Government of Canada; the European Commission; and donors to the CGIAR Research Program on Agriculture for Nutrition and Health (A4NH). HarvestPlus is also supported by the John D. and Catherine T. MacArthur Foundation.

Conflicts of interest. None.

\section{References}

Amemiya, K. 2001. "The Importance of Being Japanese in Bolivia". Japan Policy Research Institute Working Paper 75.

Andersen, L., and D. Verner. 2009. "Social Impacts of Climate Change in Bolivia: A Municipal Level Analysis of the Effects of Recent Climate Change on Life Expectancy, Consumption, Poverty and Inequality". World Bank Working Paper 5092.

Aryal, J.P., D.B. Rahut, S. Maharjan, and O. Erenstein. 2018. "Factors Affecting the Adoption of Multiple Climate-Smart Agricultural Practices in the Indo-Gangetic Plains of India." Natural Resources Forum 42 (1): 141-158.

Bardhan, P., and C. Udry. 1999. Development Microeconomics. Oxford, UK: Oxford University Press.

Boersch-Supan, A., and V. Hajivassiliou. 1990. "Smooth Unbiased Multivariate Probability Simulators for Maximum Likelihood Estimation of Limited Dependent Variable Models." Journal of Econometrics $\mathbf{5 8}$ (3): 347-368.

Calpe, C. 2006. Rice International Commodity Profile. December 2006. Rome, Italy: Food and Agriculture Organization of the United Nations.

Cameron, A.C., and P.K. Trivedi. 2005. Microeconometrics: methods and applications. Oxford, UK: Oxford University Press.

Châtel, M., E.P. Guimarâes, Y. Ospina, F. Rodríguez, and V.H. Lozano. 2010. "Mejoramiento de poblaciones de arroz de secano empleando selección recurrente y desarrollo de variedades." In: V. Degiovani, C.P. Martínez and F. Motta (eds.), Producción Eco-Eficiente del Arroz en América Latina, Tomo I (pp. 191-206). Cali, Colombia: International Center for Tropical Agriculture.

Dalrymple, D.G. 1979. “The Adoption of High-yielding Varieties in Developing Nations." Agricultural History 53(4): 704-726.

Dalrymple, D.G. 1986. Development and Spread of High-Yielding Rice Varieties in Developing Countries. Washington, D.C.: Agency for International Development.

Donkoh, S.A., S.B. Azumah, and J.A. Awuni. 2019. "Adoption of Improved Agricultural Technologies among Rice Farmers in Ghana: A Multivariate Probit Approach." Ghana Journal of Development Studies 16(1): 47-67.

FAO. 2011. "Communication for Agricultural Innovation in Bolivia: The Challenge of Institutionalization. Case Study." Rome: Communication for Sustainable Development Initiative (CSDI). 93 pp.

FAOSTAT. 2020. "Food and Agriculture Organization of the United Nations." Available at http://www.fao. org/faostat/en/.

Feder, G., R. Just, and D. Zilberman. 1985. "Adoption of Agricultural Innovations in Developing Countries: A Survey." Economic Development and Agricultural Change 33(2): 255-298.

Foster, D.A., and M. Rosenzweig. 2010. "Microeconomics of Technology Adoption." Annual Review of Economics 2(1): 395-424.

Gebremariam, G., and W. Tesfaye. 2018. "The Heterogeneous Effect of Shocks on Agricultural Innovations Adoption: Microeconometric Evidence from Rural Ethiopia." Food Policy 74(1): 154-161.

Gigler, B.S. 2015. Development as Freedom in a Digital Age: Experiences from the Rural Poor in Bolivia. Washington, DC: The World Bank.

Godoy, R., J. Morduch, and D. Bravo. 1998. "Technological Adoption in Rural Cochabamba, Bolivia." Journal of Anthropological Research 54(3): 351-372.

Greene, W.H. 2012. Econometric Analysis, 7th Edition. Upper Saddle River, NJ: Prentice-Hall. 
GRiSP (Global Rice Science Partnership). 2013. Rice Almanac, 4th Edition. Los Baños, Philippines: International Rice Research Institute.

HarvestPlus. 2009. "Bolivia lanzó comercialmente semillas de arroz con mayores nutrientes." Available at http://lac.harvestplus.org/bolivia-lanzo-comercialmente-semillas-de-arroz-con-mayores-nutrientes/.

Hoffman, V., K. Probst, and A. Christinck. 2007. "Farmers and Researchers: How Can Collaborative Advantages Be Created in Participatory Research and Technology Development?" Agriculture and Human Values 24(1): 355-368.

Kanyenji, G.M., W. Oluoch-Kosura, C.M. Onyango, and S.K. Ng'ang'a. 2020. "Prospects and Constraints in Smallholder Farmers' Adoption of Multiple Soilcarbon Enhancing Practices in Western Kenya." Heliyon 6(3): e03226, 1-10.

Kassie, M., M. Jaleta, B. Shiferaw, F. Mmbando, and M. Mekuria. 2013. "Adoption of Interrelated Sustainable Agricultural Practices in Smallholder Systems: Evidence from Rural Tanzania." Technological Forecasting \& Social Change 80(3): 525-540.

Labarta, R.A., A. Buriticá, D.C. Lopera, C. González, M. Del Río, S. Pérez, and R. Andrade. 2014. "Contribución del CIAT al mejoramiento genético de arroz en 7 países de América Latina." CIAT Working Paper.

Lynch, J., and E. Tasch. 1981. "Programa del CIAT para la investigación en Arroz de Secano en América Latina." Paper presented at the Seminar Estrategia de investigación y politicas agrícolas, January 14-16. International Center for Tropical Agriculture (CIAT).

Manda, J., A.D. Alene, C. Gardebroek, M. Kassie, and G. Tembo. 2016. "Adoption and Impacts of Sustainable Agricultural Practices on Maize Yields and Incomes: Evidence from Rural Zambia." Journal of Agricultural Economics 67(1): 130-153.

Marin, D., R. Andrade, R.A. Labarta, and J. Twyman. 2018. "Participación de la mujer en las decisiones sobre el uso y la intensidad de siembra de variedades de arroz en Ecuador." Cuestiones Económicas, Número especial de Economía y Género 28(3): 119-146.

Mponella, P., G.T. Kassie, and L.D. Tamene. 2018. "Simultaneous Adoption of Integrated Soil Fertility Management Technologies in the Chinyanja Triangle, Southern Africa." Natural Resources Forum 42(1): 172-184.

Nguyen, V.N., and D.V. Tran. 2002. "Rice in Producing Countries." In Food and Agriculture Organization of the United Nations (ed.), FAO Rice Information, vol. 3.

Oladimeji, T.E., O. Oyinbo, A.A. Hassan, and O. Yusuf. 2020. "Understanding the Interdependence and Temporal Dynamics of Smallholders' Adoption of Soil Conservation Practices: Evidence from Nigeria." Sustainability 12(7): 2376, 1-21.

Ortiz, A., and L. Soliz. 2007. El arroz en Bolivia. La Paz, Bolivia: Centro de Investigación y Promoción del Campesinado (CIPCA).

Pretty, J., R. Ruben, and L.A. Thrupp. 2002. "Institutional Changes and Policy Reforms." In: E. Uphoff (ed.), Agroecological Innovations: Increasing Food Production with Participatory Development (pp. 251260). London, UK: Earthscan Publishing Ltd.

Saka, J.O., V.O. Okoruwa, B.O. Lawal, and S. Ajijola. 2005. "Adoption of Improved Rice Varieties among Small-Holder Farmers in Southwestern Nigeria." World Journal of Agricultural Sciences 1(1): $42-49$.

Salazar, L., J. Aramburu, M. Gonzalez-Flores, and P. Enters. 2015. "Food Security and Productivity: Impacts of Technology Adoption on Small Subsistence Farmers in Bolivia." Inter-American Development Bank. Working Paper Series IDB-WP-567.

Suarez, S. 2014. "Determinantes de adopción e intensidad de adopción de variedades mejoradas modernas de arroz en el norte de Perú" Bachelor thesis. Economics Department, Universidad del Valle, Colombia.

Taboada, R., R. Guzman, J. Viruez, and T. Kon. 2005. "Rice Population Improvement in Bolivia." In E. Guimarães (ed.), Population Improvement: A Way of Exploiting the Rice Genetic Resources of Latin America (pp. 221-236). Rome, Italy: Food and Agriculture Organization of the United Nations.

Teklewold, H., M. Kassie, and B. Shiferaw. 2013. "Adoption of Multiple Sustainable Agricultural Practices in Rural Ethiopia." Journal of Agricultural Economics 64(3): 597-623.

Usman, T., A. Ango, and A. Barau. 2013. "Evaluation of Adoption of Improved Rice Varieties Among Small-Scale Farmers: A Case of Goronyo Local Government Area of Sokoto State, North-Western Nigeria." International Journal of Agricultural Innovations and Research 2(3): 408-414. 
Viruez, J., and R. Taboada. 2013. "Producción de arroz en Bolivia: conocimiento técnico para un manejo eficiente y rentable." Centro de Investigación Agrícola Tropical and Federación Nacional de Cooperativas Arroceras (FENCA).

Wainaina, P., S. Tongruksawattanab, and M. Qaima. 2016. "Tradeoffs and Complementarities in the Adoption of Improved Seeds, Fertilizer, and Natural Resource Management Technologies in Kenya." Agricultural Economics 47(1): 351-362.

Walker, T.S., and J. Alwang. 2015. "Crop Improvement, Adoption, and Impact of Improved Varieties in Food Crops in Sub-Saharan Africa." Montpellier, France: CAB International. CGIAR Consortium of International Agricultural Research Centers.

Ward, P.S., A.R. Bellb, K. Droppelmannc, and T.G. Bentond. 2018. "Early Adoption of Conservation Agriculture Practices: Understanding Partial Compliance in Programs with Multiple Adoption Decisions." Land Use Policy 70(1): 27-37.

White, D.S., R.A. Labarta, and E.J. Leguía. 2005. "Technology Adoption by Resource-Poor Farmers: Considering the Implications of Peak-Season Labor Costs." Agricultural Systems 85(2): 183-201.

Winters, C. 2012. "Impact of Climate Change on the Poor in Bolivia." Global Majority E-Journal 3(1): 33-43.

Wollni, M., D.R. Lee, and J.E. Thies. 2010. "Conservation Agriculture, Organic Marketing, and Collective Action in the Honduran Hillsides." Agricultural Economics 41(3-4): 373-384.

Wu, JunJie, and Bruce A Babcock. 1998. "The Choice of Tillage, Rotation, and Soil Testing Practices: Economic and Environmental Implications." American Journal of Agricultural Economics 80(3): 494511.

Yamano, T., A. Arouna, R.A. Labarta, Z.M. Huelgas, and S. Mohanty. 2016. "Adoption and Impacts of International Rice Research Technologies." Global Food Security 8(1): 1-8.

Yirga, C., Y. Atnafe, and A. AwHassan. 2015. "A Multivariate Analysis of Factors Affecting Adoption of Improved Varieties of Multiple Crops: A Case Study from Ethiopian Highlands." Ethiopian Journal of Agricultural Sciences 25(2): 29-45.

Zeng, Y., Y. Tian, K. He, and J. Zhang. 2020. "Environmental Conscience, External Incentives and Social Norms in Rice Farmers' Adoption of Pro-environmental Agricultural Practices in Rural Hubei Province, China." Environmental Technology 41(19): 2518-2532.

Cite this article: Martinez JM, Labarta RA, Gonzalez C, Lopera DC (2021). Joint adoption of rice technologies among Bolivian farmers. Agricultural and Resource Economics Review 50, 252-272. https://doi.org/ 10.1017/age.2021.9 